\title{
Basement-cover relations in the southeastern Cape Breton Highlands, Nova Scotia, Canada
}

\author{
ROBERT RAESIDE ${ }^{1 *}$ AND AMY TIZZARD \\ 1. Department of Earth \& Environmental Science, Acadia University, Wolfville, Nova Scotia, B4P 2R6, Canada \\ 2. 1036 Kolbec Road, Oxford, Nova Scotia, Canada, B0M 1P0, Canada \\ ${ }^{\star}$ Corresponding author $<$ rob.raeside@acadiau.ca $>$
}

Date received: 02 July 2014 gate accepted: 20 July 2015

\begin{abstract}
In the southeastern Cape Breton Highlands Neoproterozoic plutonic and metamorphic rocks outcrop in upland areas whereas Carboniferous sedimentary rocks are found in the river valleys and coastal lowlands. Detailed analysis of the contacts between these two groups of rocks including mapping, geometric constructions of the contact relations, structural geological investigations, petrographic analysis and geophysical map interpretations show that the basement rocks were emplaced by a thrust fault that extends at least from the Baddeck River valley to North River, and possibly includes klippen south and east of the highlands. The thrust fault transported a slab of rock with minimum thickness of $200 \mathrm{~m}$ a distance of at least $8 \mathrm{~km}$ over Horton and Windsor group rocks. East-directed translation of the thrust block likely occurred during the Alleghanian orogeny, and appears to mirror movement previously identified in the northern and western Cape Breton Highlands, implying that much of the upland geology is allochthonous, but likely rooted in the central highlands as positive flower structure.
\end{abstract}

\section{RÉSUMÉ}

Dans les hautes-terres du cap Breton du Sud-Ouest, on trouve des affleurements de roches métamorphiques et plutoniques du Néoprotérozoïque dans les hautes terres, alors que des roches sédimentaires du Carbonifère se trouvent dans les vallées des rivières et les terres basses côtières. L'analyse détaillée des contacts entre ces deux groupes de roches, y compris la cartographie, des constructions géométriques des relations de contact, des études géologiques structurales, une analyse pétrographique et des interprétations des cartes géophysiques, montrent que les roches du socle ont été mises en place par une faille de chevauchement qui sétend au moins depuis la vallée de la rivière Baddeck jusqu'à la rivière North, et comprend peut-être la klippe au sud et à l'est des hautes terres. La faille de chevauchement a transporté un bloc de roche d'une épaisseur minimum de $200 \mathrm{~m}$ sur une distance d'au moins $8 \mathrm{~km}$ au-dessus des roches des groupes de Windsor et Horton. La translation de la nappe de chevauchement en direction est s'est probablement produite lors de lorogenèse alléghanienne et semble refléter le déplacement constaté précédemment dans les hautesterres du cap Breton du Nord et de l'Ouest, ce qui donne à penser qu'une bonne partie de la géologie des terres hautes est allochtone mais qu'elle a, selon toute probabilité, ses racines dans les hautes terres centrales comme structure en fleur positive.

[Traduit par la redaction]

\section{INTRODUCTION}

The southeastern highlands of central Cape Breton Island rise to an altitude of $300 \mathrm{~m}$ forming a plateau of Late Neoproterozoic basement rocks adjacent to lowland valleys and a coastal plain underlain by Carboniferous sedimentary rocks of the Horton and Windsor groups.
The unmistakable change in elevation from lowland sedimentary rocks to highland basement rocks has resulted in speculation as to how these older plutonic and metamorphic rocks have achieved a higher altitude than the adjacent younger sedimentary rocks. The nature of the contact between these two sets of rocks is crucial to the understanding of this problem, and has implications for the 
structural development of the Cape Breton Highlands and other upland areas of Cape Breton Island.

Two basic possibilities can be envisioned to account for the current arrangement of high-standing basement rocks adjacent to younger sedimentary rocks: a buttress unconformity developed on a deeply incised Carboniferous surface, or a fault contact. If faulted, the attitude of the fault plane may be steep in a normal or reverse fault configuration, or shallow as in a thrust. All of these arrangements have been proposed or assumed in previous studies (Kelley 1967; Milligan 1970; Currie 1977; Raeside and Barr 1990, 1992). The present study was undertaken (Tizzard 2003) to elucidate the nature of the basementcover contact in the southeastern Cape Breton Highlands, with a view to understanding the origin of the present configuration of the highlands plateau, which in turn may contribute to the interpretation of the development of this part of the Appalachian orogen.

\section{GEOLOGICAL BACKGROUND}

\section{Basement rocks}

The basement rocks of the southeastern Cape Breton Highlands form part of the Bras d'Or terrane (Fig. 1) of the Appalachian orogen (Barr et al. 1992; Raeside and Barr 1990, 1992). The Bras d'Or terrane is characterized by three main rock associations: metamorphic and igneous rocks, comprising gneiss formed at high metamorphic grade but relatively low pressure of metamorphism from pelitic to psammitic protoliths, and incorporating thin layers of marble and amphibolite; lower metamorphic

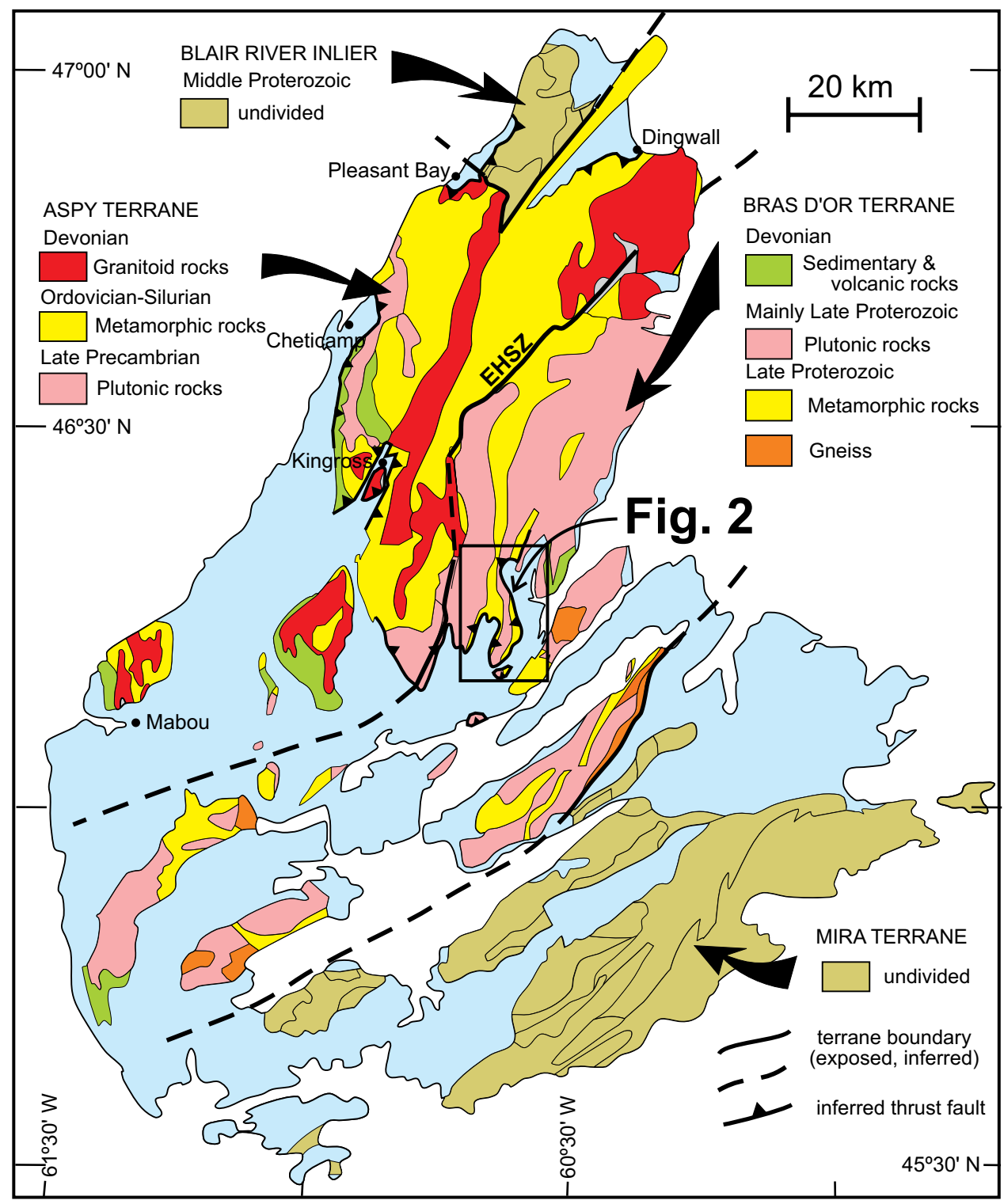

Figure 1. Simplified geological map of Cape Breton Island showing location of the area of study in the Bras d'Or terrane. Light blue background colour represents mostly Carboniferous sedimentary rocks. Boxed area is shown in Fig. 2. Inferred thrust faults outside of boxed area from Currie (1977). EHSZ = Eastern Highlands Shear Zone. 
grade dominantly clastic metasedimentary rocks, but also including minor calcareous and mafic components; and a suite of late Neoproterozoic calc-alkaline plutons and associated volcanic rocks (Raeside and Barr 1992). Barr et al. (2013) have proposed on the basis of whole-rock chemical and $\mathrm{Sm}-\mathrm{Nd}$ isotopic compositions that the high and low metamorphic grade components represent the same originally sedimentary unit at different grades of metamorphism.

The oldest units in the area of interest are the metamorphic rocks of the McMillan Flowage Formation and the Barachois River Metamorphic Suite (Fig. 2). The McMillan
Flowage Formation extends north from the study area into the central Cape Breton Highlands but in the southeastern highlands is dominantly composed of nearly vertically dipping beds of quartzite, psammite and mica schist, displaying upper greenschist-facies metamorphism. The Barachois River Metamorphic Suite outcrops as K-feldspar augen gneiss in the northern part of the area of interest, but shows lower metamorphic grade to the south where the lithologies are schist, phyllite, metasiltstone and metawacke (Shawwa 2013). All the metamorphic units share a northsouth striking, steeply to vertically dipping compositional layering and foliation, and near-vertical minor fold hinges

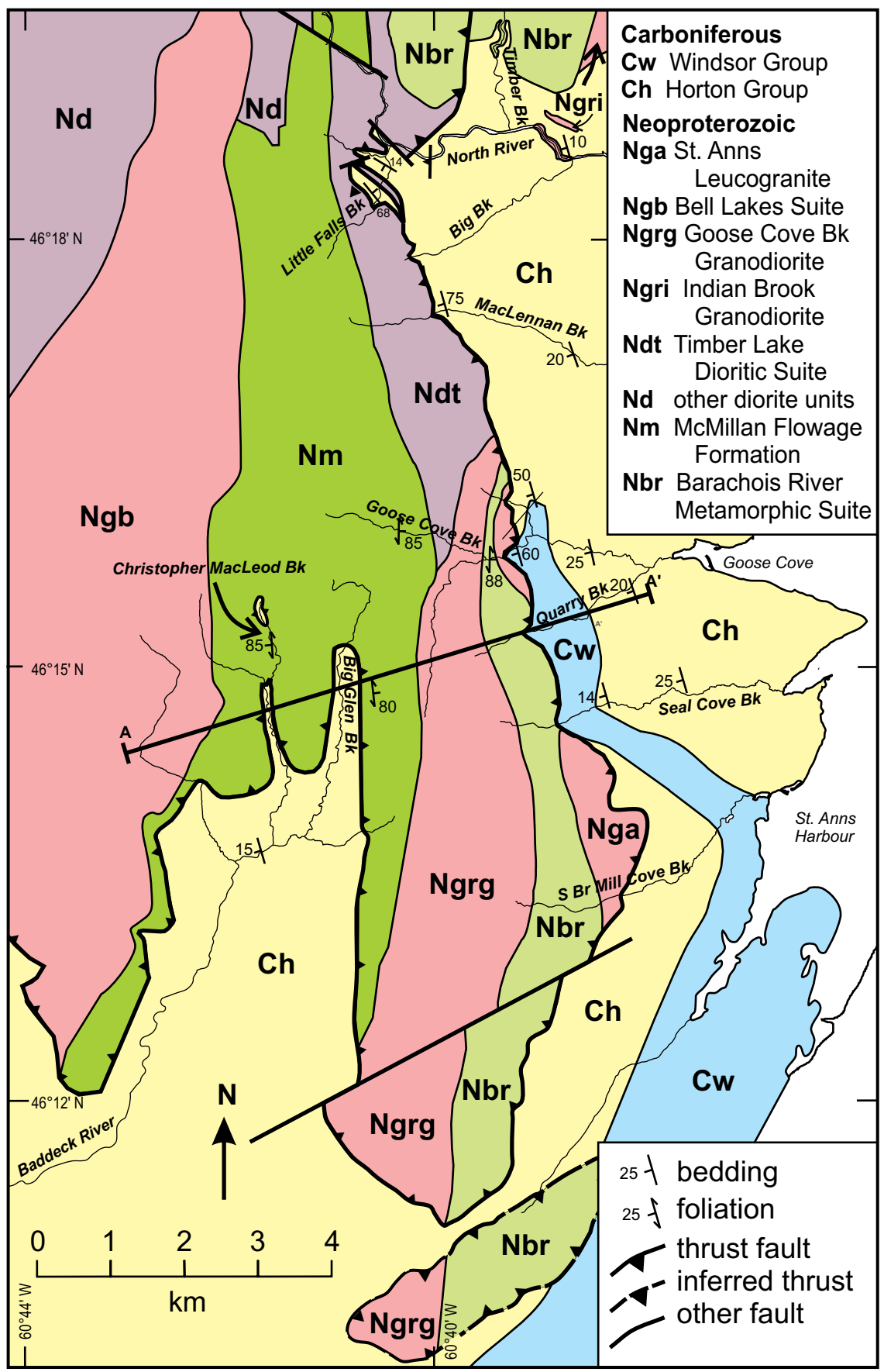

Figure 2. Detailed map of the Baddeck River - St. Anns Harbour area. 
lineations, implying deformation in a transcurrent stress regime.

Plutonic rocks in this area include the Bell Lakes Suite, consisting of three mappable plutons of granodiorite and granite, the Goose Cove Brook Granodiorite, Timber Lake Dioritic Suite, and Indian Brook Granodiorite, all of which are considered as part of the 565-555 Ma calc-alkaline plutonic rocks associated with a continental margin subduction zone (Raeside and Barr 1992). Another pluton, the St. Anns Leucogranite has yielded a younger, Cambrian age using the Rb-Sr isochron method (Cormier 1980) and may represent a later phase of plutonism. All the plutonic rocks except the St. Anns Leucogranite display some development of foliation, generally parallel to the long dimensions of the plutons and regional foliation displayed by the country rocks.

\section{Sedimentary rocks}

Carboniferous rocks of the Horton and Windsor groups are exposed in the lowland valleys and coastal plain of the southeastern Cape Breton Highlands, and generally at lower altitudes than the basement lithologies. A stratigraphic thickness of at least $600 \mathrm{~m}$ of clastic sedimentary rocks of the Horton Group is present in the coastal plain in the Goose Cove area, although Hamblin (1989a) reported 3200 $\mathrm{m}$ of Horton Group sedimentary rocks elsewhere in central Cape Breton Island. Hamblin (1989a) recognised three megafacies, a lower, thicker megafacies of distal braided stream and overbank pond deposits, passing up into mudflat, playa and braidplain deposits, a middle megafacies of deltaic fans, mudflats, shoreline and open lacustrine sedimentary rocks with thin coal seams, and an upper megafacies of sinuous fluvial and alluvial fan deposits. All these clastic rocks are dominated by coarse-grained sandstone and conglomerate, and the clast assemblage in the conglomerate is clearly derived from the plutonic and metamorphic rocks now exposed in the highlands.

Overlying the rocks of the Horton Group are shallow marine to evaporite deposits of the Windsor Group, comprising a basal stromatolitic laminated dolostone layer overlain by a sporadically developed massive gypsum layer, up to $120 \mathrm{~m}$ thick, which is in turn overlain by fossiliferous carbonate rocks and fine-grained clastic rocks typical of a sabkha-mudflat environment (Geldsetzer 1977; Hamblin 1989a).

The clastic sedimentary rocks were investigated in detail by Hamblin (1989b) who interpreted them to be deposited in fault-bounded extensional basins that were active following the Acadian orogeny, but before the Alleghanian orogeny, and show evidence for multiple episodes of fault motions. Basin fill sequences of the Horton Group resemble those of modern fault-bounded distensive basins and show no evidence of transtensive behaviour. Facies distribution and paleocurrents indicate some of the basins were half- graben structures. Later Alleghanian overprinting resulted in open folding of the Carboniferous sedimentary strata and sporadic thrust repetition and thickening of the Horton Group sequence.

\section{PETROGRAPHIC ANALYSIS}

Particular attention has been directed in this investigation to the nature of the rocks immediately adjacent to the contact between the basement and cover sequences. These rocks are found in the valleys of Baddeck River and its tributaries, and in the coastal plain west of St. Anns Harbour, central Cape Breton Island (Fig. 1). Detailed examination of these contact rocks can indicate if the basement rocks display evidence of paleoweathering, as would be expected in the case of an unconformity, or if they have been extensively deformed as would be expected in the case of a faulted contact, and in which case orientation data may be obtained to indicate the nature of the faulting.

In the western part of the area, the contact can be located to within $10 \mathrm{~m}$ in several streams around the Baddeck River valley (Fig. 2). In all cases, the exposed basement rock is metasedimentary rock of the McMillan Flowage Formation, occurring as phyllite in Christopher MacLeod Brook, chlorite schist in Baddeck River, and chlorite-muscovite schist in Big Glen Brook and at least two unnamed tributary brooks draining into it. Close to the contact, the fabric in micaceous rocks typically shows the development of a new crenulation cleavage overprinting the generally planar foliation, and more quartz-rich rocks display moderate to strong cataclasis with undulose extinction and bent mica grains (Fig. 3a).

The adjacent lithologies of the Horton Group vary from fine-grained, typically micaceous, quartz arenite to conglomerate or breccia. Quartz arenite generally contains dominantly angular to sub-angular quartz, common bent muscovite and rare feldspar grains. Conglomerate is commonly polymictic, displaying subangular, sub-rounded and angular clasts up to $8 \mathrm{~cm}$ across of local basement rock lithologies; granodiorite, diorite, and quartzite are especially common.

In Christopher MacLeod Brook the contact is exposed (under water) in one locality and can be traced to $\pm 5 \mathrm{~m}$ in a second locality. In both cases it is a highly angular unsorted oligomictic chlorite phyllite breccia containing fractured and partly broken clasts and likely tectonic in origin (Fig 3b). A similar breccia outcrops in the northernmost tributary to Big Glen Brook.

The contact between basement and cover rocks is exposed also in several brooks in the coastal plain area: Quarry Brook, Big Brook, Little Falls Brook and Timber Brook, and can be located to $\pm 10 \mathrm{~m}$ in South Branch Mill Cove Brook, Goose Cove Brook and its tributaries, and MacLennan Brook. All of these examples except the one in Timber Brook display evidence of tectonism cataclastic textures and mineralization by hematite, calcite, 



Figure 3. Petrographic and tectonic evidence for contact relations. (a) Thin section of cataclased granite, New Glen Suite, Baddeck River (crossed polars). (b) Hand sample of oligomictic phyllite breccia, Christopher MacLeod Brook. (c) Thin section of cataclased granite, St. Anns Leucogranite, Goose Cove Brook (crossed polars). (d) Chatter marks developed on sandstone, Big Glen Brook. (e) Exposed angular unconformity of well bedded sandstone over steeply dipping gneiss, Timber Brook. (f) Anhydrite-laced stretched net-texture in gypsum (Goose Cove Brook). All scales in hand sample photographs are in centimetres. 
chlorite, and/or molybdenite in granite or diorite (Fig. 3c), polished fracture surfaces in chlorite schist, chatter marks (Fig. 3d) and intense undulose extinction in quartz from quartz arenite, intense saussuritization of plagioclase, bent mica, and deformed lithic fragments in lithic arenite, and anhydrite-laced stretched net-texture in gypsum (Fig. 3f).

The contact found in Timber Brook is an exceptionally well exposed angular unconformity, which outcrops along $800 \mathrm{~m}$ of the stream, but shows no evidence of paleoweathering in the basement gneiss (Fig. 3e). The paleosurface was clearly irregular, although the extent of relief along the contact appears to be less than $20 \mathrm{~m}$. In one location where a fissure, $10 \mathrm{~cm}$ wide and $1.5 \mathrm{~m}$ deep in the gneiss, is filled with sandstone, the edges of the basement rock are angular and unweathered.

Taken collectively, the petrographic evidence for basement-contact relations overwhelmingly supports a tectonic contact in most locations, and an angular unconformity in one locality, Timber Brook. The tectonic contacts demonstrate abundant evidence for brittle deformation, with the development of cataclasite, fault breccia, and chatter marks. In some lithologies, particularly gypsum, chlorite schist, and rocks with coarse-grained mica, some evidence for ductile deformation is also found. In the case of the exposed angular unconformity, basement rocks are unweathered, and the overlying clastic sedimentary rocks were locally derived and deposited in an arid environment.

\section{STRUCTURAL ANALYSIS}

Structural analysis of the basement-cover relationship involves three main components. First, the orientations of bedding, foliation and fracture planes have been examined to give insight into the regional orientation patterns of each type of plane. Second, using outcrop orientation data and

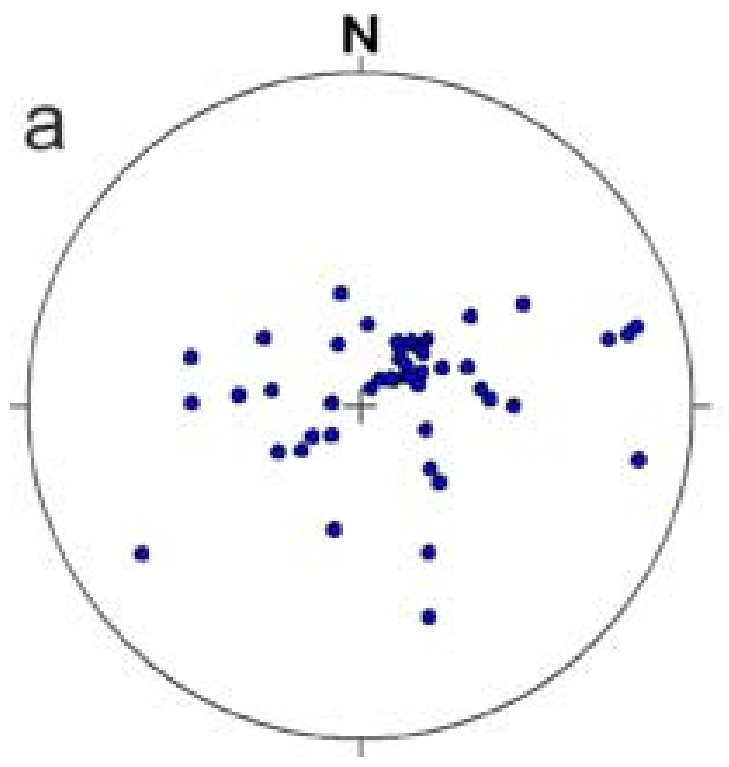

three-point problem solutions, structural contours of the contact planes were drawn for individual areas. Finally, cross sections were drawn to elucidate the relations across the area of study.

Bedding plane attitudes of Carboniferous rocks from all areas are plotted on a stereonet (Fig. 4a). A scatter of orientations is obvious, with a concentration of bedding planes dipping gently to the WSW, reflecting the overall attitude of bedding across the area (Fig. 2), away from areas of intense localized deformation and the immediate vicinity of the tectonized basement contacts. This cluster of poles includes the bedding seen at the unconformity in Timber Brook (Fig, 3e; the scene here is viewed looking to the north, with the unconformity dipping to the west at about $15^{\circ}$ ). Bedding is disrupted adjacent to the tectonized contacts with basement: in Little Falls Brook and Big Brook bedding in sandstone is both steepened and tightly folded; in Goose Cove Brook geopetal structures involving partly filled brachiopod cavities in limestone demonstrate overturned, moderately steeply dipping rocks; and in Christopher MacLeod Brook bedding is both steepened and severely interrupted by small-scale faulting and fracturing.

The attitudes of foliation and fracture planes were also measured in the field, although as many of the basement rocks are granitic, they lack prominent measurable foliation. Foliations in both the McMillan Flowage Formation (Baddeck River area) and Barachois River Metamorphic Suite (coastal plain area) are uniformly northerly striking, with steep to near-vertical dips. Fracture planes also provide little further information about the basementcover relations - measurements of 122 fracture planes in all units show a broad scatter of orientations across a stereonet with no apparent clustering.

As the actual contact between basement and cover rocks occurs as a tectonic breccia in most of the observed contact areas, it is not generally possible to measure in outcrop the

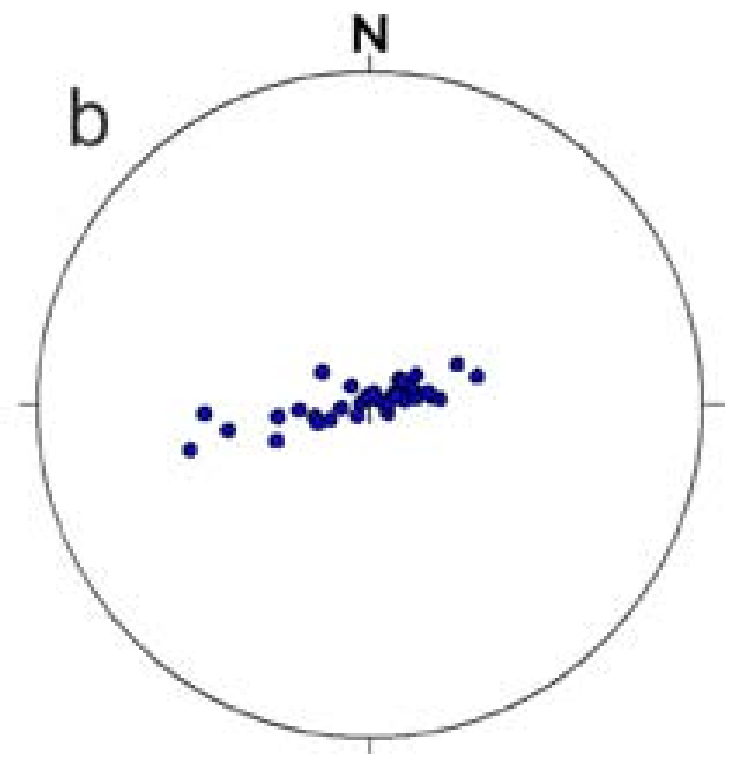

Figure 4. Orientation data for (a) bedding in Carboniferous units; (b) multiple three-point problem solutions. 
orientation of the contact plane. Only in Little Falls Brook is the basement-cover contact exposed as a sharp plane, but there the orientation (northwesterly strike, $70^{\circ}$ dip to the northeast) is likely modified by imbrication. In an attempt to obviate local effects associated with movement at the contact, and to deduce the more regional orientation of the contact plane, a series of three-point problems was devised around the area. Using three known or tightly constrained contact locations that outcrop in a triangle, it is possible to construct geometrically the strike and calculate the dip of the plane of interest as demonstrated in Fig. 5.

Three-point problems were constructed around the study area, 12 in the Baddeck River area, and 21 in the eastern domain. In most cases, these constructions are based on the lowest (elevation) outcrops of the basement rock or the highest outcrops of sedimentary rocks, and therefore serve to bracket the maximum and minimum possible dips of the contact in that area. The poles to inferred planes are plotted on Fig. 4b, which shows a cluster of planes with shallow WSW dips, coincident with the cluster of poles to bedding across the area. The scatter of poles along a WSW-ENE great circle demonstrates that the strike of the basement-cover contact is relatively constant, but that dip varies widely - however most of this variation is the result of the assuming the contact is at the lowermost basement contact or uppermost cover rocks contact in each threepoint problem. Using geologically 'reasonable' constraints, e.g., the last appearance (going up-stream) of sedimentary rocks in the stream-bed boulder assemblage, or prominent changes in slope of ridge shoulders, the scatter shown $\left(75^{\circ}\right)$ can be reduced to less than $30^{\circ}$, with the cluster remaining in the same location on the stereonet. The typical aspect of the contact can be recognized as a gently westward-dipping plane (Fig. 6).

The third structural technique employed to analyse the basement-cover relation is the construction of large-scale

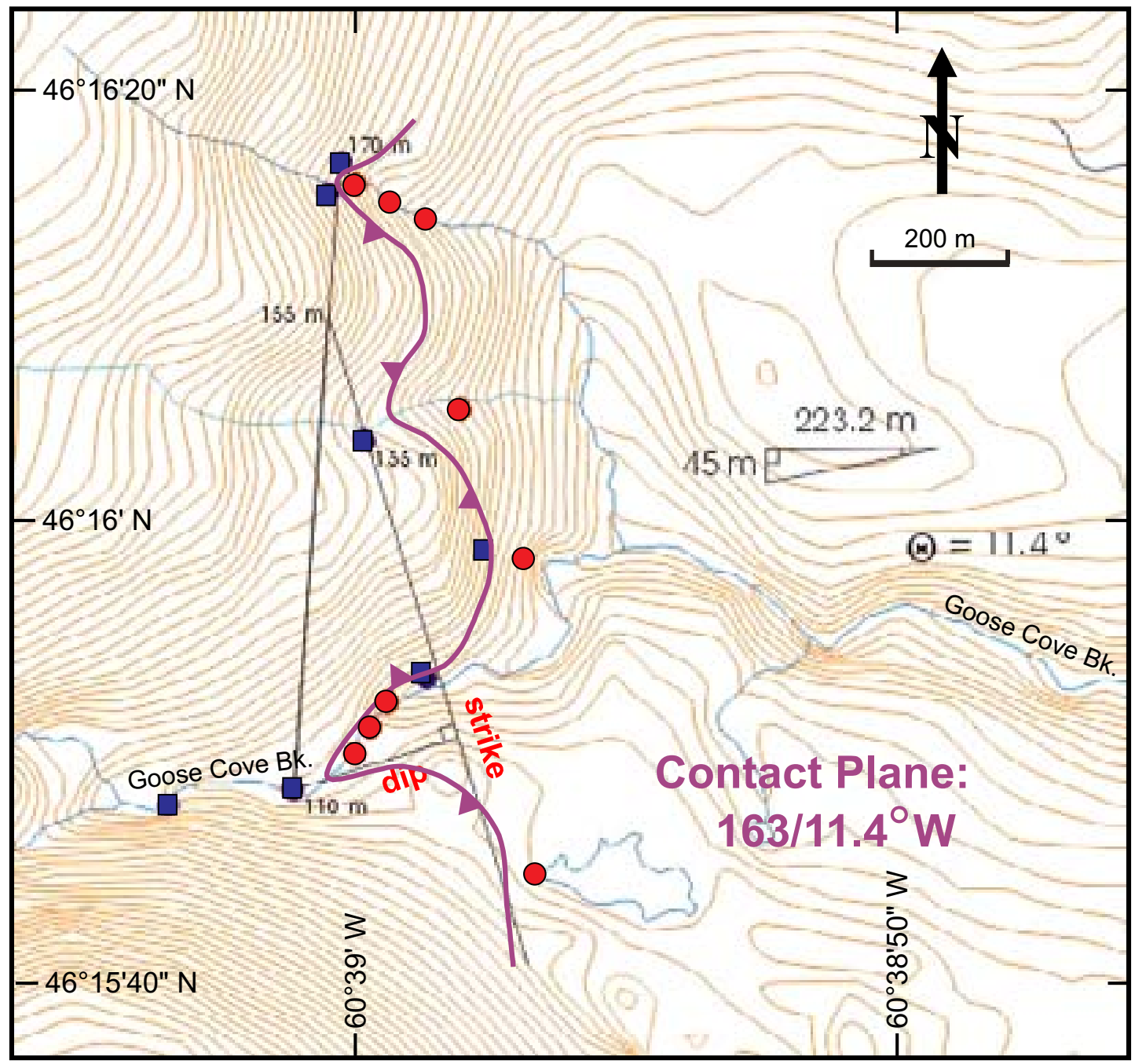

Figure 5. Construction of a three-point problem in the Goose Cove Brook area. The lowermost outcrops of basement rocks in three streams are selected as the base points for the construction. The construction yields a contact orientation of $163^{\circ} / 11^{\circ} \mathrm{W}$. Blue squares: lowermost outcrops on hillside of basement rocks; red circles: uppermost outcrops on hillside of Carboniferous rocks. 


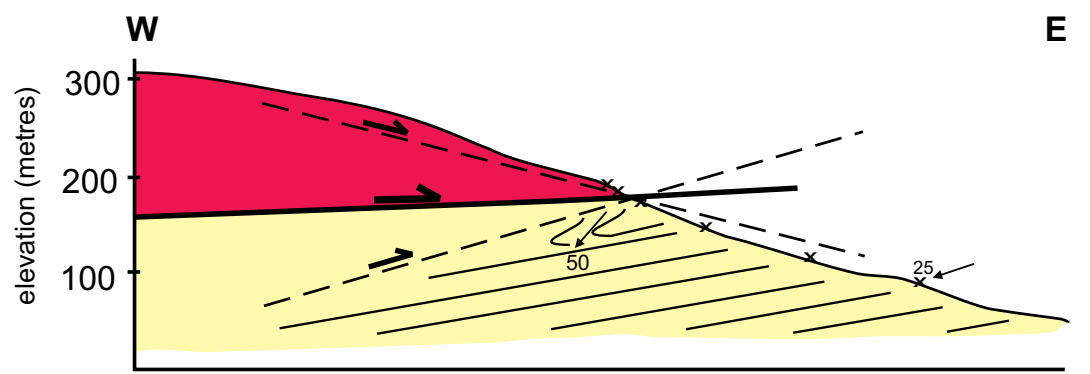

Carboniferous sedimentary rocks

$\square$ Pre-Carboniferous basement rocks

x rock outcrops used to constrain cross-section
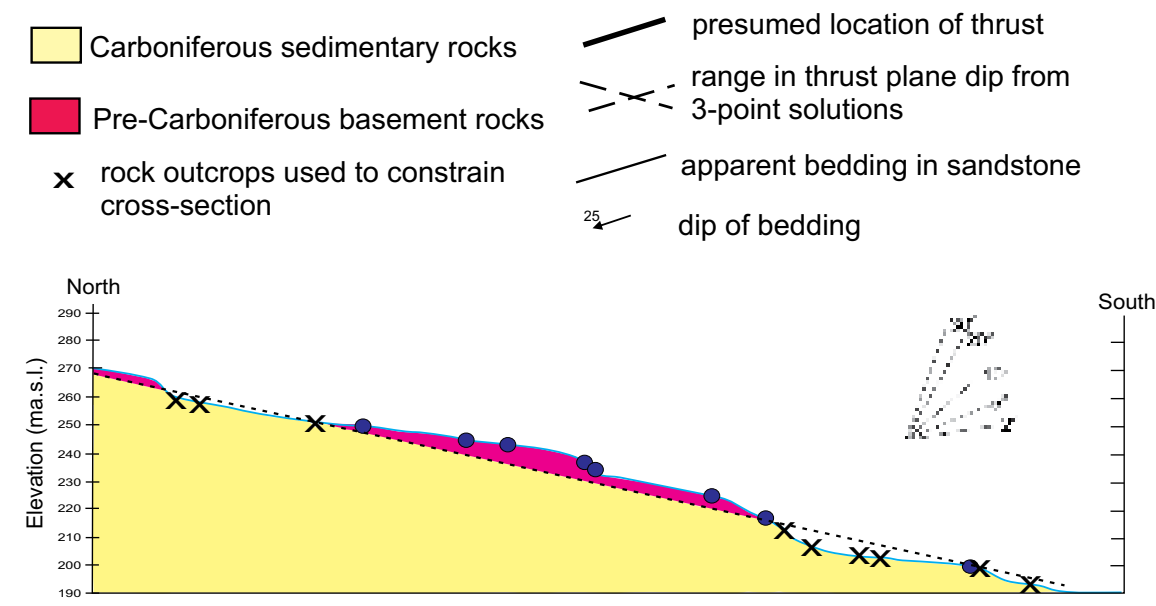

Ground distance (approx. $1770 \mathrm{~m}$ ) 5x Vertical Exaggeration

Xarboniferous sedimentary outcrops
Pre-Carboniferous basement outcrops
$\square$ Carboniferous sedimentary rocks
$\square$ Pre-Carboniferous basement rocks

cross-sections where sufficient outcrop allows. In most cases these are drawn along stream sections. Christopher MacLeod Brook offers the best location in the Baddeck River area, where phyllite and sandstone alternate in outcrop down the stream (Fig. 2). A longitudinal profile (effectively a north-south cross-section along the stream) was constructed to demonstrate the spatial relationship between the basement and sedimentary rocks (Fig. 7). Using this profile it is possible to establish a line of best fit as a contact plane between the overlying basement rocks and the sedimentary rocks below them. Without vertical exaggeration, the angle of best fit is a plane dipping $3^{\circ}$ to the south, representing the apparent dip in this north-south section. The tilt to the east or west cannot be determined in this south-flowing stream. The outcrops of Carboniferous sedimentary rocks upstream in Christopher MacLeod brook are now interpreted as a window through a shallowdipping thrust plane that has transported the basement rocks over the younger rocks. Chatter marks in sandstone (Fig. 3d) and slickenlines in chlorite schist both indicate movement was from west to east, on an azimuth of 090$100^{\circ}$.

Recognising that the Precambrian basement rocks are thrust over the Carboniferous sedimentary units, it is possible to interpret several other features in the Baddeck
Figure 6. Detail of the Goose Cove Brook area showing the possible range of dips of the contact, the preferred orientation and the nature of drag folding in the underlying sedimentary units. Dashed lines are the limiting cases for thrust fault dip in this section, solid line (and colour change) represents the best fit scenario.

Figure 7. Longitudinal profile of Christopher MacLeod Brook showing inferred dip of the contact plane between the basement and sedimentary rocks. Angular scale shows the appearance of dip values given $5 \mathrm{x}$ vertical exaggeration.
River - St. Anns Harbour area as the product of this displacement. Tectonized contacts across most of the area are the product of movement on the thrust plane(s). In most cases these are brittly deformed, so it is likely that the thickness of basement rock carried on these thrust planes was never large. Steepening of bedding, reversal of dip direction, and in at least one location overturned bedding appear to be the drag effect of movement on the overlying thrust plane (Fig. 6). This section, in the Goose Cove Brook area, does not have sufficient outcrop area to restrict the three-point problem solutions uniquely, so the range of possible contact planes is presented. The preferred solution is for a west-dipping thrust plane, approximately midway in the range of possibilities, and almost parallel to the regional bedding in the Carboniferous beds. Overturned beds, demonstrated by inverted geopetal structures in limestone immediately below the thrust, indicate eastward translation of the thrust sheet over them. Chatter marks in the sandstone immediately below the thrust in the Big Glen area also support an eastward movement of the over-riding slab. Similarly, slickenlines in chlorite schist developed from the St. Anns Leucogranite in the Goose Cove Brook area support an eastward translation of the thrust plate. Lastly, in the northern part of the area, imbrication of the thrust structure has occurred, resulting in repetition of the thrust 
plane and basement-cover contact in Little Falls Brook. Imbricated repetition of caliche limestone in a duplex structure in the North River area appears to be related to the emplacement of the thrust slice, but is directed toward the west - this opposing thrust fault arrangement may be akin to a triangle zone structure, as recognised in the Alberta Rockies (Ollerenshaw 1978), and demonstrates that brittle deformation also continued through the Carboniferous rocks in some areas.

North of North River, the thrust faults cuts into the basement rocks of the Barachois River Metamorphic Suite, along a zone of highly foliated sheared gneiss, in which a pronounced slaty cleavage is developed. North of the area of Figure 2, zones with strongly sheared lithologies continue northward for at least $5 \mathrm{~km}$, into the Timber Brook Dioritic Suite, and may represent an extension of this zone of movement.

The evident unconformable contacts in Timber Brook and in the lower reaches of North River, where windows through the Carboniferous sequence reveal underlying units of diorite, granodiorite, gneiss and mylonite, lie to the east of the main block of thrusted rocks, and appear to be unrelated to the thrust contacts identified here. The thrust therefore does not exploit the basement-cover contact, and presumably in some locations must cut it.

\section{GEOPHYSICAL EVIDENCE}

Remotely sensed geophysical techniques were employed by Ethier (2001) to infer subsurface geology that is not evident by traditional geological mapping methods. A vertical gradient magnetic anomaly (VGM) map fused with a shaded relief digital elevation model (DEM) was used to trace the locations of basement rocks in areas where outcrop is poor. Basement rocks comprise a wide range of variably magnetic lithologies (diorite, granodiorite, granite, quartzite, phyllite and gneiss), commonly extending as narrow north-south trending units across this part of the Cape Breton Highlands. As such they tend to show highly variable signatures in the VGM map, unlike the Carboniferous sedimentary rocks which tend to have low magnetic variability (Fig. 8).

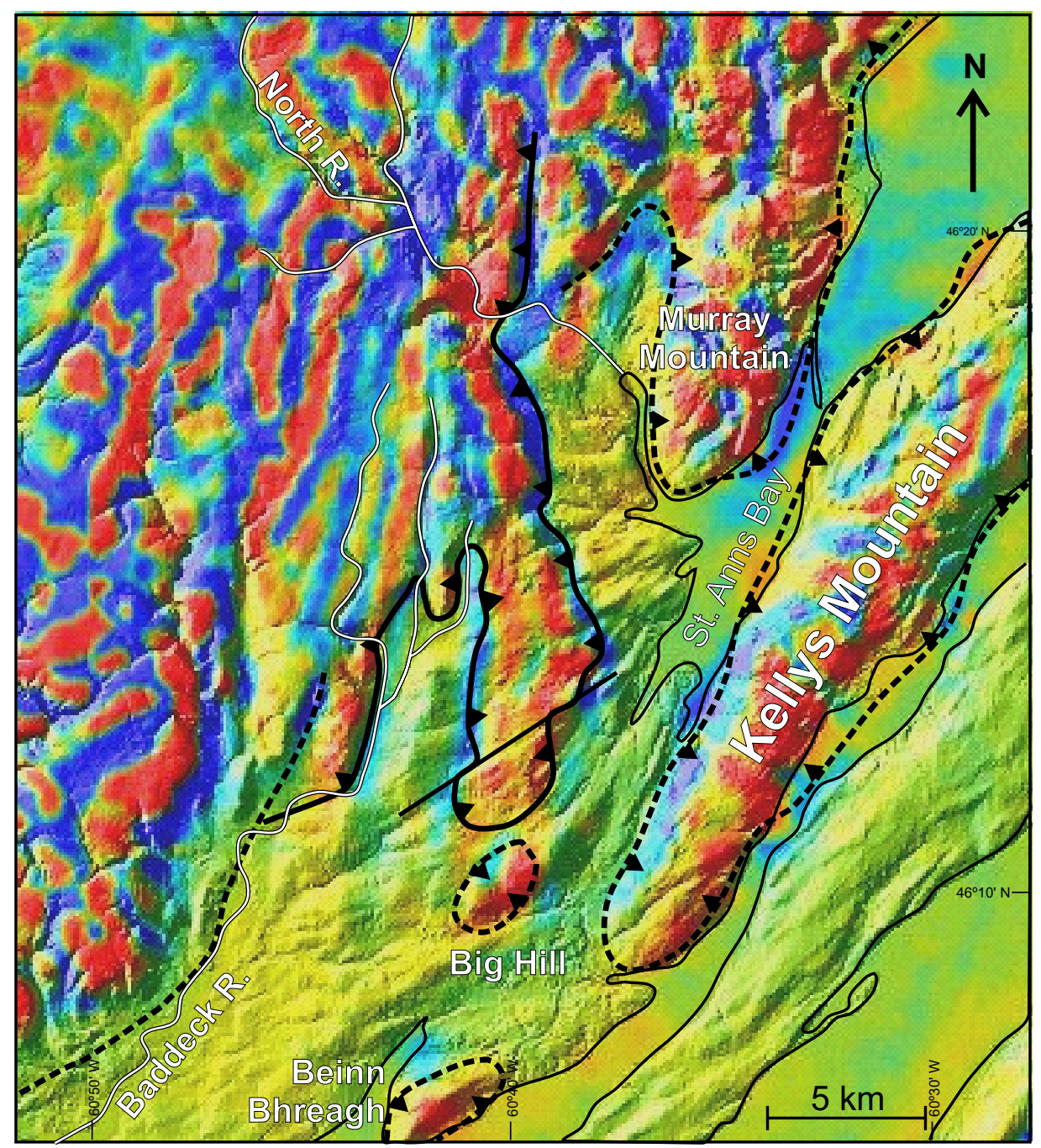

Figure 8. Vertical gradient magnetic anomaly map fused with shaded relief digital elevation model (from Ethier 2001), with position of thrust contact added. Solid lines are the thrust faults identified in this study; dashed lines are other potential thrust blocks. 
Although the geophysical data are limited in their application, the trends are sufficiently clear to identify that the ridge of thrusted basement rocks between the Baddeck River Valley and the coastal plain correlates with an area of high magnetic relief on Fig. 8. A southerly extension, now separated by erosion, can be detected in the Big Hill area, and possibly again at Beinn Bhreagh (Fig. 8). Beyond the area of detailed structural investigation that is the focus of this paper, the VGM-DEM map also suggests that Murray Mountain might be allochthonous and even that Kellys Mountain might be an eastern klippe. However, steep faults with unknown displacement are thought to lie along the eastern edge of the Cape Breton Highlands and extend into St. Anns Bay (Barr et al. 1992), so continuity of horizontal structures across to Kellys Mountain is tenuous.

Ethier (2001) also compiled a Bouguer gravity map fused with DEM (Fig. 9), which reveals a regional northeastsouthwest trend of gravity variations in the southeastern Cape Breton Highlands, oblique to the trends shown by the VGM analysis, mapped lithological variations, and the orientation of the thrust plane. Although gravity measurements are sparse in this area, gravity values are higher in the northern part of the study area, and tail off in the southeastern highlands, compatible with an interpretation of a thrust fault transporting a thin veneer of basement rocks over younger sedimentary rocks with no root of plutonic rocks in Baddeck River-St. Anns Harbour area. Likewise, none of the inferred possible klippen (Big Hill, Beinn Bhreagh, Murray Mountain) display any expression in the gravity data, also suggestive of an allochthonous nature for these blocks.

\section{REGIONAL SIGNIFICANCE}

Recognition of thrust displacement of Precambrian basement rocks over Carboniferous sedimentary strata raises questions concerning the direction of movement of the thrust sheet, the timing of displacement, and regional extent of such thrusting. Limited evidence exists for kinematic analysis of the movement on the thrust fault

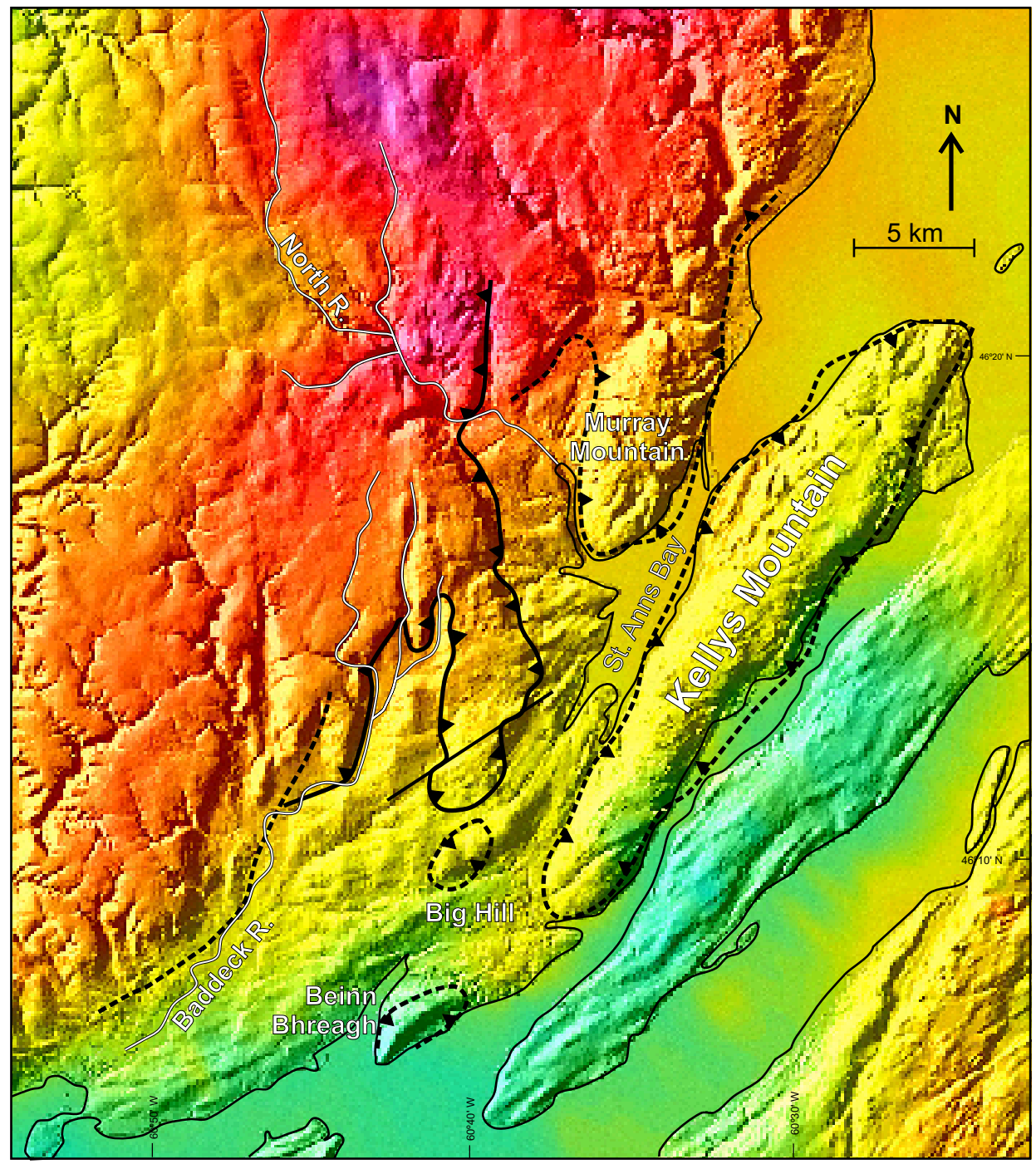

Figure 9. Bouguer gravity map fused with a shaded relief digital elevation model of the southeastern highlands revealing a regional northeast-southwest trend of gravity variations in the study area (modified from Ethier 2001). 
plane: north-south oriented chatter marks in the New Glen Brook area and slickenlines and crystal fibre lineations oriented $090-100^{\circ}$ in the Goose Cove Brook area (Fig. $3 \mathrm{~d}$ ) are broadly indicative of a generally easterly transport direction. Using this direction of transport and restoring palinspastically the basement rocks now exposed in the ridge between Baddeck River valley and the St. Anns Bay lowlands, it can be demonstrated that the thrust has displaced rocks over the Carboniferous sequence at least 8 km (Fig. 10).

Movement on the thrust plane postdated the deposition of the Windsor Group carbonate and evaporite rocks (Visean, 342-327 Ma). The movement was therefore well after the end of Acadian deformation. Lynch and Tremblay (1994) and Lynch and Giles (1996) proposed the extensional Ainslie detachment, a large low-angle extensional fault localized near the base of the Windsor Group in the western Cape Breton Highlands, detected by a layer of calc-mylonite and a stratigraphic gap within the Windsor Group. Although the timing of this motion is broadly compatible with the thrusting in the southeastern highlands, the extensional nature of motion of the Ainslie detachment appears incompatible with thrust faulting elsewhere. Waldron et al. (2013) documented the role of evaporite tectonics in the development of Pennsylvanian sedimentary basins in northern mainland Nova Scotia, some of which could have been contemporaneous with the thrust movements in Cape Breton Island. However, although the displacement of salt may have caused displacement locally, the main role of this event appears to have been in basin formation. Salt is not known in the various outcrop areas of the Windsor Group around the periphery of the Cape Breton Highlands, and deformation in gypsum (Fig. 3f) appears to be restricted to the immediate vicinity of the fault plane.

Hamblin (1989a) described repetition of sections of the Horton Group by thrust faults in drillholes in the Southwest Mabou River area and postulated this movement occurred during the Alleghanian orogeny. The timing of such thrust faulting is compatible with the observations in the southeastern Cape Breton Highlands.

Thrust faulting was invoked for basement-cover relations in the northern and northwestern Cape Breton Highlands at localities near Dingwall, Pleasant Bay, Cheticamp and
Kingross, also as a result of motion in the Alleghanian orogeny (Currie 1977). All these examples required displacement of Precambrian or Lower Paleozoic basement rocks over Horton and Windsor group sedimentary rocks, but in a northerly or westerly direction. The total displacement that can be demonstrated in these examples is up to $3 \mathrm{~km}$, but the potential exists for much more.

With the recognition of thrust faulting in the southeastern Cape Breton Highlands, and the previous identification of similar structures with opposite vergence in the northwestern highlands (Currie 1977), the question arises, where did the mass of material originate? One solution to this problem is to postulate a large positive flower structure, rooted in the central highlands, with displacement in opposite directions on either side of the main mass of the highlands. Several lines of evidence can be advanced to support this hypothesis. The regional Bouguer gravity anomaly reported by Ethier (2001) crosses north-striking surficial geological units obliquely, implying deeper level structures lie on a NNE to NE trend. The Eastern Highlands Shear Zone has been recognized to display a protracted period of motion (Lin 1995), although the dominant phase of mylonite development ended in the Late Devonian. Late Neoproterozoic plutonic rocks in the southeastern highlands display telescoping of units (Farrow and Barr 1992, Grecco and Barr 1999), with increasingly greater amounts of uplift toward the northwest. Similarly, telescoping in the opposite direction has been recognized in the western highlands (Craw 1984) using metamorphic zonal assemblages. However, most of the available radiometric age data from the plutonic and metamorphic rocks record Neoproterozoic to Devonian movement, too old to correlate with the post-Windsor Group thrusting identified here. It is more likely that the thrust motions now identified were produced by late shallow horizontal tectonics, possibly initially associated with these earlier transpressive structures. The current levels of erosion demonstrate that horizontal translation can be constrained to a minimum of $8 \mathrm{~km}$ of movement, but the brittle nature of the deformation textures in the rocks of the fault planes indicate that all horizontal translation occurred under nonmetamorphic conditions.

\section{Regional vertical cross-section from A to $A^{\prime}$}

Christopher MacLeod Brook area to Quarry Brook

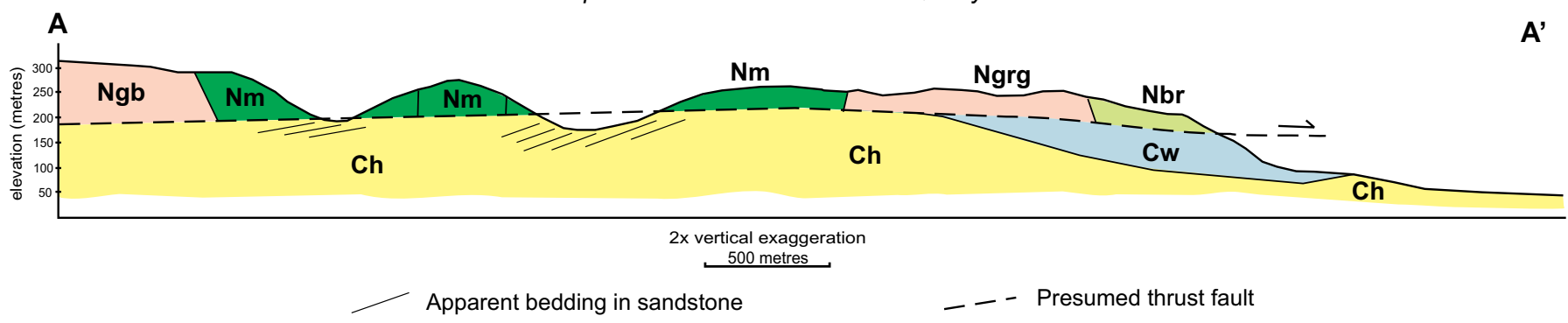

Figure 10. Cross-section across the thrust block. Units identified on Figure 2. 


\section{CONCLUSIONS}

Abundant evidence exists in the form of contact relations and deformation of Carboniferous sedimentary rocks for a period of thrust faulting that translated a thrust slab of Neoproterozoic basement rocks eastward from the central Cape Breton Highlands over the Carboniferous rocks for a distance of at least $8 \mathrm{~km}$, and possibly as much as $15-20 \mathrm{~km}$. Thin section petrographic analysis of the autochthonous sedimentary rocks indicates a predominance of brittle deformation, with brittle-ductile deformation only evident in gypsum. The thrust fault appears to be a single plane over an area of at least $300 \mathrm{~km}^{2}$, but shows some evidence of imbrication in the northern part of the study area. The plane lies sub-horizontally across the entire area, with no evidence of step and ramp geometry. Beds immediately below the thrust fault plane are abundantly deformed, with drag fold development resulting in locally overturned units. VGM maps support the interpretation of a thin thrust slice incorporating rocks of high magnetic variability in the north-south ridges and klippen of the southeastern Cape Breton Highlands, but Bouguer gravity anomaly maps do not reveal the feature. As the gravity anomalies are associated with deeper level structures, the geophysical maps support the interpretation of a thin slab of rock transported on the thrust plane. A minimum thickness of $200 \mathrm{~m}$ remains across the area.

The thrust fault occurred after the deposition and lithification of the Visean Windsor Group, and most likely took place during the Alleghanian orogeny in the Late Carboniferous to Permian. Other open fold structures are evident in the Carboniferous rocks that can be attributed to this event.

Similar thrust structures have been identified by Currie (1977) in the northern and western Cape Breton Highlands, also based on the geometry of basement rocks observed sitting on sedimentary rocks in valleys deeply incised into the highlands. The interpretation of easterly vergent thrusting in the southeastern highlands therefore mirrors the structures to the north and west and implies that the latest phases of movement in the Cape Breton Highlands were bivergent, with material being translated in opposite directions during Late Carboniferous deformation. This could only be possible during a period of convergent or transpressive tectonics, implying the Cape Breton Highlands formed in a restraining bend structure in intercontinental tectonism during this time frame.

\section{ACKNOWLEDGMENTS}

The authors gratefully acknowledge the Natural Sciences and Engineering Research Council and Acadia University for funding to advance this study, Paul Barker for field assistance and the staff at the Gaelic College for logistical support for the field component of the study. The manuscript was improved by constructive reviews by Deanne van Rooyen and Becky Jamieson, who are acknowledged with thanks.

\section{REFERENCES}

Barr, S.M., Pin, C., McMullin, D.W.A., and White, C.E. 2013. Whole-rock chemical and $\mathrm{Sm}-\mathrm{Nd}$ isotopic composition of a Late Proterozoic metasedimentary sequence in Ganderia: Kellys Mountain, Bras d'Or terrane, Nova Scotia, Canada. Atlantic Geology, 49, pp. 57-69. http://dx.doi.org/10.4138/atlgeol.2013.002

Barr, S.M., Raeside, R.P., and Jamieson, R.A. 1992. Geology of northern Cape Breton Island, Nova Scotia. Geological Survey of Canada Coloured Map 1752A, scale 1:100 000.

Cormier, R.F. 1980. New rubidium/strontium ages in Nova Scotia. Nova Scotia Department of Mines and Energy, Report 80-1, pp. 223-233.

Craw, D. 1984. Tectonic stacking of metamorphic zones in Cheticamp River area, Cape Breton Highlands, Nova Scotia. Canadian Journal of Earth Sciences, 21, pp. 1229-1244. http://dx.doi.org/10.1139/e84-128

Currie, K.L. 1977. A note on post-Mississippian thrust faulting in northwestern Cape Breton Island. Canadian Journal of Earth Sciences, 14, pp. 2937-2941. http:// dx.doi.org/10.1139/e77-254

Ethier, M. 2001. Re-interpretation of the geology of the Cape Breton Highlands using combined remote sensing and geological databases. Unpublished M.Sc. thesis, Acadia University, Wolfville, Nova Scotia, $126 \mathrm{p}$.

Farrow, C.E.G. and Barr, S.M. 1992. Petrology of high-Alhornblende and magmatic epidote bearing plutons in the southeastern Cape Breton Highlands, Nova Scotia. Canadian Mineralogist, 30, pp. 377-392.

Geldsetzer, H.H.J. 1977. The Windsor Group of Cape Breton Island, Nova Scotia. Report of Activities, Part A, Geological Survey of Canada, Paper 77-1A, pp. 425-428.

Grecco, L.E. and Barr, S.M. 1999. Late Neoproterozoic granitoid and metavolcanic rocks of the Indian Brook area, southeastern Cape Breton Highlands, Nova Scotia. Atlantic Geology, 35, pp. 43-57. http://dx.doi. org/10.4138/2023

Hamblin, A.P. 1989a. Basin configuration, sedimentary facies, and resource potential of the Lower Carboniferous Horton Group, Cape Breton Island, Nova Scotia. In Current Research, Part B, Geological Survey of Canada, Paper 89-1B, pp. 115-120. 
Hamblin, A.P. 1989b. Sedimentology, tectonic control and resource potential of the Upper Devonian-Lower Carboniferous Horton Group, Cape Breton Island, Nova Scotia. Unpublished Ph.D. thesis, University of Ottawa, Ottawa, Ontario, 300 p.

Kelley, D.G. 1967. Baddeck and Whycocomagh map areas with emphasis on Mississippian stratigraphy of central Cape Breton Island, Nova Scotia (11K/02 and 11F/14). Geological Survey of Canada, Memoir 351, 65 p.

Lynch, G. and Giles, P.S. 1996. The Ainslie Detachment: a regional flat-lying extensional fault in the Carboniferous evaporitic Maritimes Basin of Nova Scotia. Canadian Journal of Earth Sciences, 33, pp. 169-181. http://dx.doi. org/10.1139/e96-016

Lynch, G. and Tremblay, C. 1994. Late DevonianCarboniferous detachment faulting and extensional tectonics in western Cape Breton Island, Nova Scotia, Canada. Tectonophysics, 238, pp. 55-69. http://dx.doi. org/10.1016/0040-1951(94)90049-3

Milligan, G.C. 1970. Geology of the George River Series, Cape Breton, Stratigraphy, Structure, and Economic Geology. Nova Scotia Department of Mines, Memoir 7, $111 \mathrm{p}$.

Ollerenshaw, N.C. 1978. Calgary. Geological Survey of Canada Map 1457A, scale 1:250 000.
Raeside, R.P. and Barr, S.M. 1990. Geology and tectonic development of the Bras d'Or suspect terrane, Cape Breton Island. Canadian Journal of Earth Sciences, 27, pp. 1371-1381. http://dx.doi.org/10.1139/e90-147

Raeside, R.P. and Barr, S.M. 1992. Preliminary report on the geology of the northern and eastern Cape Breton Highlands, Nova Scotia. Geological Survey of Canada Paper 89-14, 39 p.

Shawwa, N. 2013. Employing contact metamorphism to assess the conditions of pluton emplacement in southwestern Kellys Mountain, Cape Breton Island, Nova Scotia. Unpublished B.Sc. Honours thesis, Acadia University, Wolfville, Nova Scotia, $128 \mathrm{p}$.

Tizzard, A.M. 2003. Structural geology and basement-cover relations in the southeastern Cape Breton Highlands, Nova Scotia. Unpublished B.Sc. Honours thesis, Acadia University, Wolfville, Nova Scotia, 95 p.

Waldron, J.W.F., Rygel, M.C., Gibling, M.R., and Calder, J.H. 2013. Evaporite tectonics and the late Paleozoic stratigraphic development of the Cumberland basin, Appalachians of Atlantic Canada. GSA Bulletin, 125, pp. 945-960. http://dx.doi.org/10.1130/B30718.1

Editorial responsibility: David P. West, Jr. 